\title{
MENINGKATKAN KEMAMPUAN MEMBACA PEMAHAMAN ANAK GANGGUAN INTELEKTUAL RINGAN DENGAN MENGGUNAKAN METODE KLOSE
}

\author{
Purwani Budi Astuti \\ e-mail: purwanibudiastuti@gmail.com \\ FIP Universitas Negeri Jakarta
}

\begin{abstract}
Abstrak: Anak gangguan intelektual ringan perlu memiliki kemampuan membaca agar dapat mengikuti perkembangan pembelajaran secara optimal. Namun, sering terjadi anak tidak memiliki kemampuan tersebut sehingga tidak dapat memahami isi bacaan dengan tepat. Melalui penelitian tindakan kelas, penelitian ini bermaksud mengatasi masalah itu khususnya untuk siswa kelas V SDLB C Dian Kahuripan. Untuk meningkatkan kemampuan membaca pemahaman siswa gangguan intelektual ringan, peneliti menggunakan metode klose. Penelitian dilakukan di SDLB C Dian Kahuripan, Jakarta Timur. Setelah melalui dua sikulus, penelitian ini menemukan peningkatan kemampuan membaca pemahaman anak. Dengan demikian disimpulkan metode klose dapat diterapkan pada anak dengan gangguan intelektual ringan melalui serangkain kegiatan di dalamnya.
\end{abstract}

Kata Kunci: anak gangguan intelektual ringan, membaca pemahaman, metode klose

\section{IMPROVING READING COMPREHENSION COMPETENCE BY CLOSE METHOD FOR THE CHILDREN OF DISORDER INTELLECTUALLY UN- DEMANDING}

\begin{abstract}
The children of disorder intellectually undemanding should have reading comprehension competence to be able to follow the instructional development optimally. However, many children do not have such competence that they can not understand the reading passages properly. To solve the problem, this research conducted a classroom action research in the fifth grade of SDLB C Dian Kahuripan, Jakarta. Employing Close method in two cycles, the research discovered significant improvement of the students' reading comprehension competence. The research concludes that Close method with a number of techniques and activities is effective to solve the reading comprehension problems faced by the children of disorder intellectually undemanding
\end{abstract}

Keywords: the children of disorder intellectually undemanding, reading comprehension, Close method

\section{PENDAHULUAN}

Kemampuan berbahasa Indonesia mencakup aspek mendengarkan, berbicara, membaca dan menulis. Kemampuan membaca penting diperoleh bagi anak gangguan intelektual ringan supaya mereka dapat mengikuti perkembangan pembelajaran secara optimal serta memupuk keyakinan diri di sekolah sebab tanpa keterampilan membaca anak-anak akan menghadapi kesulitan dalam belajar bidang lain serta kehilangan minat untuk belajar.

Anak gangguan intelektual ringan umumnya memiliki perkembangan tubuh yang normal, dari segi intelektual memiliki tingkat kecerdasan 50-70 dan anak gangguan intelektual ringan ini memiliki potensi di bawah anak normal namun mereka masih mampu dididik walaupun lambat dalam menerima pelajaran.

Mata pelajaran bahasa Indonesia untuk siswa gangguan intelektual ringan di SDLB C ditetapkan sesuai dengan kondisi yang ada pada mereka dan guru mengupayakan pengembangan dan peningkatan potensi yang mereka miliki.
Penguasaan keterampilan belajar membaca lazim dibagi dalam dua tahapan yaitu keterampilan membaca permulaan dan keterampilan membaca pemahaman atau membaca lanjut. Kedua keterampilan membaca ini merupakan kontinuitas dalam belajar membaca.

Siswa di kelas V SDLB C Dian Kahuripan sudah dapat membaca lancar namun mereka belum mampu memahami isi bacaan. Hal ini banyak dipengaruhi oleh beberapa faktor diantaranya dari dalam diri anak itu sendiri yakni pada dasarnya anak gangguan intelektual ringan sangat terbatas dalam memikirkan hal-hal yang abstrak dan mengalami kesulitan dalam memusatkan perhatian, dengan keterbatasan kemampuan berpikir tersebut mereka sudah tentu mengalami kesulitan dalam belajar terutama dalam pelajaran Bahasa Indonesia dan khususnya pada membaca pemahaman. Selain faktor tersebut juga dipengaruhi oleh faktor dari luar diri siswa yaitu karena kurangnya teknik-teknik khusus untuk mengembangkan lingkungan belajar, serta pendekatan pembelajaran yang digunakan harus memberikan kesempatan kepada 
siswa untuk memperoleh hasil belajar melalui aktivitas yang menyenangkan, dan oleh pendidik, pembelajaran Bahasa Indonesia kurang diprioritaskan sebagai mata pelajaran yang dapat mengembangkan kemampuan siswa sehingga hasil belajar kurang maksimal.

Pada umumnya penggunaan pendekatan pembelajaran masih berorientasi pada aktivitas guru seperti menyuruh siswa untuk membaca dan memahami bacaan, bukan pendekatan yang berorientasi pada aktivitas siswa seperti mengajak siswa untuk mengajukan pendapatnya, pembelajaran ini guru lebih banyak mendominasi dalam aktivitas pembelajaran sedangkan siswa tidak mempunyai peran dalam proses kegiatan belajar mengajar atau siswa pasif. Berdasarkan hal tersebut di atas, untuk mengatasinya agar pembelajaran membaca pemahaman memperoleh hasil yang lebih meningkat maka guru perlu menggunakan pendekatan pembelajaran yang dapat mengaktifkan dan dapat mengembangkan kemampuan siswa.

Penggunaan metode yang tepat dan benar dalam membaca dapat meningkatkan hasil belajar. Saat ini terdapat berbagai metode membaca yang dapat meningkatkan pemahaman siswa terhadap suatu bacaan. Namun dalam pelaksanaannya masih banyak guru yang menggunakan cara-cara lama atau metode tradisional yaitu dengan cara guru menunjuk seorang siswa untuk membaca nyaring suatu teks bacaan sebanyak satu paragraf dan siswa yang lain menyimak kemudian bergilir, siswa yang lain meneruskan paragraf berikutnya. Setelah teks terbaca semua dilanjutkan siswa menjawab pertanyaan bacaan. Cara ini kurang dapat mengembangkan kemampuan membaca pemahaman karena siswa kurang mendapat kesempatan untuk mengadakan latihan memahami isi bacaaan sehingga banyak pertanyaan bacaan yang tidak terjawab dengan benar

Sebagai pilihan untuk mengatasi permasalahan dalam meningkatkan kemampuan membaca pemahaman siswa gangguan intelektual ringan kelas V SDLB $C$, peneliti memberikan jalan keluar melalui metode klose. Metode klose merupakan metode pembelajaran yang melatih siswa berpikir mencari kata-kata yang tepat untuk mengisi kekosongan dalam bacaan serta membantu siswa meningkatkan pemahaman terhadap bacaan.

Mengingat pentingnya keterampilan membaca pemahaman bagi anak gangguan intelektual ringan di SDLB C maka peneliti akan mencoba menggunakan metode klose dalam pembelajaran membaca pemahaman. Berdasarkan identifikasi dan pembatasan masalah tersebut, peneliti merumuskan masalah pene- litian "Apakah metode klose dapat meningkatkan kemampuan membaca pemahaman anak gangguan intelektual ringan kelas V SDLB C Dian Kahuripan Jakarta Timur?"

\section{Kajian Teoretis}

\section{Hakikat Membaca}

a. Pengertian Membaca

Klein, dkk dalam Rahim (2007: 3) mengemukakan bahwa definisi membaca mencakup: (1) membaca merupakan suatu proses, (2) membaca adalah strategis, dan (3) membaca merupakan interaktif. Membaca merupakan suatu proses artinya informasi dari teks dan pengetahuan yang dimiliki oleh pembaca memiliki peran yang sangat berarti dalam membentuk makna. Membaca adalah strategis artinya membaca yang efektif menggunakan berbagai cara membaca yang sesuai dengan teks dan masalah dalam rangka memahami makna ketika membaca. Membaca adalah interaktif yaitu keterlibatan pembaca dengan teks sangat bermanfaat untuk memperoleh tujuan yang ingin dicapai sehingga seseorang mudah memahami teks yang dibacanya.

Menurut Tim Penulis Bahasa Indonesia UTASMI (2002: 3) membaca adalah kegiatan berbahasa yang secara aktif menyerap informasi atau pesan yang disampaikan melalui media tulis seperti buku, artikel, modul, surat kabar atau media tulis lainnya. Disebut aktif karena membaca juga mengandung arti membangun makna, memahami, menerima, menolak, membandingkan, dan meyakini isi tulisan. Dengan demikian membaca dapat menambah pengetahuan apabila dilakukan dengan aktif tidak sekedar mengetahui saja tetapi dipahami dan diyakini.

Menurut Kosadi (1990: 74) membaca meliputi pengenalan kembali kata-kata dan struktur-struktur. Bagi orang yang belum mengenal huruf membaca merupakan pengenalan huruf-huruf, arti kata, dan struktur kalimat sebelum memahami makna bacaan yang terkandung didalamnya.

Dari beberapa definisi yang dikemukakan para ahli di atas dapat disimpulkan bahwa membaca merupakan kegiatan berbahasa secara aktif, menyerap informasi, serta aktivitas fisik yang terkait dengan gerak mata serta ketajaman penglihatan dan aktivitas mental yang mencakup ingatan, dan pemahaman yang pada dasarnya merupakan suatu proses komunikasi manusia dengan media cetak, menafsirkan dan memberi makna pada suatu wacana berupa bahan tertulis. Sedangkan bagi anak yang belum mengenal huruf, membaca merupakan awal untuk pengenalan huruf sebelum memahami makna bacaan yang terkandung didalamnya.

Perspektif Ilmu Pendidikan - Vol. 25 Th. XVI April 2012 


\section{b. Proses Membaca}

Membaca merupakan proses sensoris. Isyarat dan rangsangan aktivitas membaca masuk melalui indra penglihatan, atau tangan untuk orang tunanetra. Penglihatan menyerap informasi tulis kemudian meneruskannya ke otak dan otak mengolahnya. Seseorang jika mengalami gangguan pada kedua inderanya akan kesulitan mengenali tulisan. Dengan demikian, kemampuan sensoris merupakan prasyarat awal untuk dapat mendeteksi huruf atau rangkaian huruf, tanda baca, dan berbagai lambang tulis lainnya.

Proses membaca meliputi dua proses, yaitu proses decoding atau dikenal dengan istilah membaca teknis dan proses pemahaman. Dalam membaca teknis, simbol-simbol huruf atau kata diubah menjadi sistem bunyi sehingga memiliki makna. Sedangkan dalam proses membaca pemahaman terjadi penelaahan terhadap kata, kalimat, dan konteks kalimat secara struktural, semantik, maupun apresiatif.

Dari definisi tersebut di atas, dapat disimpulkan bahwa proses membaca adalah suatu kegiatan yang melibatkan indera terutama indera penglihatan dan rangsangan. Proses membaca dapat dibagi menjadi dua yaitu proses membaca teknis dan proses membaca pemahaman. Dalam proses membaca teknis simbolsimbol huruf diubah menjadi sistem bunyi sehingga memiliki makna, sedangkan dalam proses pemahaman, penelaahan kata, kalimat, dan konteks kalimat secara struktural, sistematik, maupun apresiatif .

\section{c. Tujuan Membaca}

Menurut Broto (1980: 12) tujuan membaca adalah; (1) membaca teknik bertujuan agar siswa lebih lancar mengenal tulisan, tanda-tanda baca serta dapat mengucapkan dan melagukan bahasa; dan (2) membaca bahasa bertujuan agar siswa dapat memahami isi yang dibaca. Membaca teknik bertujuan agar siswa lancar membaca dengan lafal dan intonasi yang benar sedangkan membaca bahasa bertujuan agar siswa memahami isi bacaan.

Menurut Hayon (2003: 58), tujuan membaca dibagi atas dua bagian, yaitu untuk memahami wacana dan menilai isi wacana yang memerlukan daya nalar terlatih dan wawasan pengetahuan yang luas. Pembaca biasanya hanya sampai pada memahami wacana, jarang sampai pada menilai wacana karena bagian ini memerlukan daya nalar yang terlatih dan wawasan pengetahuan yang luas.

Tujuan membaca menurut Rahim (2007: 11), membaca hendaknya mempunyai tujuan, karena membaca dengan suatu tujuan, cenderung lebih memahami dibandingkan dengan orang yang tidak mempunyai tujuan. Adapun tujuan membaca men- cakup: (1) kesenangan, (2) menyempurnakan membaca nyaring, (3) menggunakan strategi tertentu, (4) mengaitkan informasi baru dengan informasi yang telah diketahuinya, dan (5) menjawab pertanyaanpertanyaan yang spesifik.

Dari beberapa definisi tujuan membaca tersebut, dapat penulis simpulkan bahwa membaca mempunyai tujuan memperlancar membaca dengan intonasi sesuai tanda baca, memahami isi bacaan, memperoleh kesenangan dari bacaan, memperbaharui pengetahuan, memperoleh informasi, dan dapat menjawab pertanyaan yang spesifik.

d. Faktor faktor yang Mempengaruhi Keberhasilan Membaca

Menurut Subyantoro dan Pratiwi (2000:18) keberhasilan membaca dipengaruhi oleh faktor dalam dan luar dirinya. Inteligensi, sikap, penguasaan bahasa, perbedaan kelamin pada usia muda, dan perbedaan logatnya dengan bahasa bacaan adalah faktor dalam diri siswa. Sedangkan faktor luar diri siswa, meliputi: kondisi bacaan, bahasa, isi, dan tingkat keterbacaan, kesesuaian bacaan dengan daya tangkap pembaca, status sosial ekonomi, dan pengajaran membaca guru yang membinanya. Apapun faktor yang berpengaruh terhadap keberhasilan membaca dapat dibina secara formal melalui pengajaran membaca yang dirancang, diprogramkan, serta dilaksanakan dengan baik.

Menurut Lamb dan Arnorl dalam Rahim (2008:16) faktor yang mempengaruhi kemampuan atau keberhasilan membaca ialah faktor fisiologis, intelektual, lingkungan, dan psikologis. Faktor fisiologis mencakup kesehatan fisik, pertimbangan neurologis, dan jenis kelamin. Faktor intelektual bahwa intelegensi ialah kemampuan global individu untuk bertindak sesuai dengan tujuan, berpikir rasional, dan berbuat secara efektif terhadap lingkungan. Faktor lingkungan mencakup latar belakang pengalaman siswa di rumah dan sosial ekonomi keluarga siswa. Faktor psikologis mencakup motivasi, minat, kematangan sosial, emosi, dan penyesuaian diri.

Dari kedua pendapat di atas, dapat diperoleh sebuah pengertian bahwa faktor yang mempengaruhi keberhasilan membaca adalah faktor dari dalam dan dari luar diri anak, yaitu faktor fisiologis, faktor lingkungan, dan faktor psikologis.

\section{Hakikat Membaca Pemahaman}

a. Pengertian Membaca Pemahaman

Membaca sesungguhnya merupakan upaya di dalam memahami dan menafsirkan pikiran serta kehendak yang dinyatakan dalam tulisan. Orang dikatakan telah memiliki keterampilan membaca apabila telah sampai kepada pemahaman dari suatu teks yang 
disampaikan penulisnya. Memahami makna apa yang terdapat dibalik teks itulah makna sesungguhnya dari membaca pemahaman.

Menurut Sugono (2003: 105), membaca cermat dilakukan orang untuk memperoleh pemahaman sepenuhnya terhadap isi bacaan atau buku yang dibacanya. Dengan membaca cermat, seseorang akan dapat mengingat dan memahami ide pengarang, karakter tokoh (dalam bacaan fiksi), konsep-konsep khusus, hubungan antar bagian, atau gaya penulisan.

Menurut Amin (1995: 211) membaca pemahaman yang diistilahkan dengan membaca lanjut dilakukan tanpa suara yang penting pembaca dapat menangkap pikiran, perasaan, sikap, dan keinginan penulis. Membaca pemahaman dilakukan dalam hati tanpa suara sehingga pembaca dapat menangkap isi dari bacaan.

Dari ketiga pendapat di atas, secara lengkap diperoleh sebuah pengertian mengenai membaca pemahaman yakni suatu kemampuan membaca untuk memahami isi bacaan, memahami ide pengarang, dapat menangkap pikiran, dan perasan penulis.

b. Komponen-komponen dalam Membaca Pemahaman

Menurut Hayon (2003: 59), komponen-komponen atau unsur-unsur dari pemahaman sebuah wacana adalah: (1) memahami kata, kalimat, rangkaian kalimat dengan kalimat lain; (2) membedakan ide yang penting dan kurang penting yang utama dan bukan; (3) membuat dugaan dan kesimpulan; dan (4) membuat sari atau inti pesan. Untuk dapat memahami sebuah wacana haruslah menguasai komponen-komponen dalam membaca, adapun penerapannya dari teori Hayon komponen membaca bagi anak gangguan intelektual ringan hanya pada memahami kata, rangkaian kalimat dengan kalimat lain, serta membuat inti pesan.

Menurut Sunardi (1997: 1), untuk dapat menguasai kemampuan membaca pemahaman diperlukan pengembangan kosa kata, pemahaman literal, pemahaman inferensial, membaca kritis atau evaluatif, dan penguasaan apresiasi.

Keterampilan membaca menurut versi Boer dan Dallman seperti dikutip oleh Sadtono keterampilan membaca antara lain: (1) menemukan pokok-pokok pikiran dari suatu bacaan, (2) menjawab pertanyaan bacaan, (3) meringkas isi bacaan, (4) menemukan kesimpulan umum, (5) mengikuti petunjuk yang diberikan dalam bacaan, dan (6) memahami arti kalimat dan hubungan kalimat dalam parangraf-parangraf pada keseluruhan teks bacaan secara utuh (Subyantoro dan Pratiwi, 2000: 17).
Dari beberapa pendapat di atas, yang dapat diterapkan bagi anak gangguan intelektual ringan, yaitu: (1) memahami kata, kalimat, rangkaian kalimat dengan kalimat lain, (2) menjawab pertanyaan bacaan (3) pengembangan kosa kata, (4) memahami dan mengingat informasi secara tersurat pada wacana, dan (5) membuat sari atau inti pesan.

3. Tahap-tahap Perkembangan Membaca Pemahaman

Menurut Harris seperti yang dikutip oleh Abdurrahman (2003: 202), ada lima tahap dalam perkembangan membaca, yaitu: tahap kesiapan membaca, tahap membaca permulaan, tahap keterampilan membaca, tahap membaca luas, dan tahap membaca sesungguhnya.

Tahapan membaca tersebut dapat dijelaskan sebagai berikut: (1) tahap kesiapan membaca terjadi sejak anak lahir hingga anak diberikan pelajaran membaca. Pada tahap ini anak diperkenalkan dengan cerita dan gambar-gambar; (2) tahap membaca permulaan umumnya terjadi saat anak memasuki usia enam tahun. Anak mulai dilatih sikap duduk dalam membaca yang baik, cara memegang buku yang benar, diperkenalkan dengan simbol, huruf- huruf, kata- kata dan kalimat sederhana; (3) tahap keterampilan membaca cepat terjadi saat anak duduk di kelas dua dan tiga pada tahap ini anak mulai diajarkan cara membaca teks pendek dan panjang dengan memperhatikan pelafalan dan intonasi yang tepat; (4) tahap membaca luas terjadi saat anak duduk di kelas empat dan lima. Pada tahap ini umumnya anak telah mampu memahami isi bacaan dengan baik. Anak dapat menjawab pertanyaanpertanyaan bacaan seperti apakah ide pokok dari bacaan, fakta yang terjadi dalam bacaan, nama tokoh dalam bacaan, pesan yang ingin disampaikan penulis dan lain sebagainya; dan (5) tahap membaca sesungguhnya adalah tujuan sebenarnya dari membaca. Tahap ini dimaksudkan bahwa anak tidak lagi belajar untuk membaca, melainkan membaca untuk belajar misalnya anak mulai menerapkan kemampuan membacanya untuk memahami bidang studi lain. Tahap ini terjadi saat anak telah duduk di sekolah lanjutan dan berlanjut hingga dewasa.

Dari beberapa pendapat ahli di atas, dapat disimpulkan, bahwa untuk dapat memahami isi bacaan maka diperlukan kematangan gerak motorik mata dan tahapan-tahapan perkembangan membaca yang perlu dilalui. Dengan demikian, anak tidak lagi belajar untuk membaca melainkan membaca untuk belajar memahami bidang studi lain. Sedangkan untuk anak gangguan intelektual ringan kelas $\mathrm{V}$ dalam penelitian ini sampai pada tahap memahami isi bacaan yaitu menjawab pertanyaan bacaan.

Perspektif Ilmu Pendidikan - Vol. 25 Th. XVI April 2012 


\section{Hakikat Anak Gangguan Intelektual Ringan}

a. Pengertian Anak Gangguan Intelektual Ringan

Menurut Abdurrahman dan Sudjadi (1994:

26-27) anak gangguan intelektual ringan tergolong subnormal akan mengalami kesulitan dalam mengikuti program reguler di sekolah dasar namun mereka masih memiliki potensi untuk menguasai mata pelajaran akademik di sekolah dasar, mampu menyesuaikan diri dalam masyarakat, dan mampu bekerja untuk menopang sebagian atau seluruh kehidupan orang dewasa. Kemampuan anak gangguan intelektual ringan tergolong di bawah normal namun mereka masih memiliki potensi untuk menguasai mata pelajaran akademik di sekolah dasar dan mampu menyesuaikan diri dalam masyarakat.

Menurut Riadi, dkk (1984: 54), anak gangguan intelektual ringan adalah istilah lain dari debil atau moron secara pedagogis tingkat intelegensi tergolong rendah, namun masih dapat dididik secara khusus dengan program dan metode yang khusus. Anak ini intelegensinya tergolong rendah namun masih dapat dididik secara khusus dengan program dan metode yang khusus.

Dari beberapa definisi yang dikemukakan oleh para ahli di atas dapat simpulkan, bahwa anak gangguan intelektual ringan adalah anak yang memiliki intelegensi antara 50-70, masih mampu beradaptasi seperti anak normal, dapat melakukan pekerjaan dengan mengandalkan keterampilan berpikir sederhana. Namun pada bidang akademik, mereka tertinggal dengan anak normal seusianya.

b. Karakteristik Anak Gangguan Intelektual Ringan

Agar pelayanan kepada anak gangguan intelektual ringan diberikan sesuai dengan kebutuhan maka perlu memahami dan mengerti tentang karakteristiknya. Adapun karakteristik anak gangguan intelektual ringan menurut Riadi dkk (1984: 54-55) ialah IQ nya antara 50-70 sama dengan anak normal umur 7-12 tahun paling tinggi, dapat menyelesaikan pendidikan sekolah dasar sampai kelas IV atau V, sifatnya mudah dipengaruhi orang lain dan nafsu birahinya tinggi. Keadaan fisik anak gangguan intelektual ringan sama dengan anak normal namun gerakan tidak lincah, bicaranya sukar dan sulit menyesuaikan diri dengan lingkungan, sifatnya mudah dipengaruhi dan suka melakukan perintah orang lain, emosinya meledakledak, mudah naik darah bila diganggu, keras kepala, dan cemburuan, lekas putus asa, dorongan seks kuat, tidak dapat menilai baik buruk, dan agresif.

Menurut yang tertulis dalam The New American Webster sebagaimana diterjemahkan oleh Amin (1995: 37) bahwa kecerdasan berpikir seseorang gangguan intelektual ringan paling tinggi sama dengan kecerdasan anak normal usia 12 tahun.

Dari beberapa pengertian di atas, dapat peneliti simpulkan, bahwa anak gangguan intelektual ringan pada umumnya berbicaranya lancar tetapi perbendaharaan kata-katanya kurang, tidak dapat berpikir abstrak, namun masih dapat mengikuti pelajaran akademik di sekolah biasa maupun di sekolah khusus pada umur 16 tahun baru mencapai umur kecerdasan sama dengan anak 12 tahun, dan penampilan hampir sama dengan anak normal.

c. Faktor-faktor yang Mempengaruhi Anak Gangguan Intelektual Ringan dalam Membaca Pemahaman

\section{1) Faktor Kemampuan}

Menurut Efendi (2006: 98), kemampuan membaca anak gangguan intelektual ringan prestasi tertinggi bidang baca, tulis, dan hitung tidak lebih dari anak normal setingkat kelas III-IV sekolah dasar.

Eisenson dan Ogilvie meneliti mencari hubungan antara tingkat kecerdasan dengan kemampuan bahasa dan bicara. Hasilnya dapat dibuktikan, bahwa antara tingkat kecerdasan dengan kematangan bahasa dan bicara mempunyai hubungan yang positif. (Efendi, 2006:99)

Menurut Amin (1995: 205) mata pelajaran kelompok akademis hanya diberikan pada anak gangguan intelektual ringan. Mata pelajaran ini menekankan pada pengembangan kemampuan berpikir logis, konseptual, dan analisis sederhana. Mata pelajaran kelompok akademis tersebut adalah membaca, menulis, dan berhitung.

Dari pendapat yang dikemukakan oleh para ahli tersebut di atas, maka dapat penulis simpulkan bahwa kemampuan maksimal anak gangguan intelektual ringan dalam membaca setingkat anak kelas III atau IV sehingga terdapat hubungan positif antara tingkat kecerdasan dengan kemampuan bahasa dan bicara sedangkan untuk mata pelajaran kelompok akademisnya seperti membaca, menulis, dan berhitung menekankan pada pengembangan kemampuan berpikir logis, konseptual, dan analisis sederhana.

2) Faktor Umur, Kecepatan Belajar, dan Lingkungan

Mengajar membaca pada anak gangguan intelektual perlu memperhatikan tiga hal berikut ini, yaitu.

a) Faktor umur

Mengajar membaca pada anak gangguan intelektual tidak dapat disandarkan pada umur. Pada waktu ia berumur enam tahun kecerdasannya sama dengan anak umur tiga sampai empat setengah tahun. Jadi, anak gangguan intelektual yang berumur enam 
tahun belum matang untuk belajar membaca. Kecerdasan yang hampir sama dengan umur enam tahun baru dicapainya pada umur sembilan sampai dua belas tahun. Pada umur inilah anak gangguan intelektual matang untuk belajar membaca.

b) Faktor kecepatan belajar

Dalam jangka waktu pendek, kecepatan belajar anak gangguan intelektual sama dengan anak normal, yang sama umur kecerdasannya dengannya. Akan tetapi, dalam jangka waktu yang panjang mereka akan jauh ketinggalan dari anak tersebut, misal anak gangguan intelektual umur sepuluh tahun mempunyai kecerdasan yang sama dengan anak normal umur tujuh tahun. Kalau anak itu belajar bersama dengan anak normal mungkin mencapai prestasi yang sama. Akan tetapi, setelah satu tahun dia baru mencapai umur kecerdasan delapan tahun atau lebih. Jelas anak gangguan intelektual tersebut ketinggalan dengan anak normal tersebut.

c) Faktor lingkungan

Dalam bahasa maupun dalam pengalamanpengalaman lain banyak anak gangguan intelektual yang kurang mendapat kesempatan untuk berkembang. Orang-orang disekitarnya banyak yang tidak suka mengajaknya bercakap-cakap atau bermain. Jadi kesempatan pengembangan dirinya kurang. Sekolah inilah yang mengisi kekosongan tersebut dengan program yang memperkaya pengalaman dan kesempatan berbicara (Amin, 1995: 215).

Anak gangguan intelektual ringan perlu mendapat pelayanan yang baik serta perhatian dari lingkungan sekitar. Dengan demikian sekolah memegang peranan yang sangat berarti untuk pengembangan diri maka tepatlah penelitian ini dilaksanakan bagi anak gangguan intelektual ringan.

\section{Desain Alternatif Intervensi Tindakan}

\section{Hakikat Metode Klose}

Metode ini diperkenalkan oleh Taylor yang berasal dari istilah closure suatu istilah dari ilmu jiwa Gestalt, yang menyatakan bahwa kecenderungan orang untuk melengkapi suatu pola yang tidak lengkap menjadi suatu kesatuan yang utuh dengan melihat bagian-bagian sebagai suatu keseluruhan. Jadi, setiap individu di dalam proses belajar mempunyai pemahaman yang sempurna. Pemahaman itu didapatkan dengan mengisi bagian yang tidak lengkap atau bagian yang dihilangkan. Tugas pembaca adalah mengisi bagian-bagian yang kosong itu dengan kata yang tepat.

Menurut Sunardi (1997: 18) prosedur klose adalah metode untuk mengukur tingkat kemampuan membaca pemahaman yang terdiri dari lebih kurang 250 kata, kalimat pertama dan terakhir dibiarkan utuh mulai kalimat ke dua setiap kata ke sepuluh dihilangkan untuk kemampuan anak tingkat permulaan sedangkan untuk tingkat lanjut penghilangan dapat dilakukan pada setiap kata ke lima. Metode klose yaitu dengan cara anak membaca bacaan dan mengisi titiktitik dengan kata sinonimnya. Ada beberapa variasi klose yakni disediakan daftar kata yang dapat dipakai untuk mengisi titik-titik ada pula yang penghilangan kata tidak dibuat teratur setiap kata ke-n tetapi dipilih jenis kata kerja saja, atau kata benda saja, dan kemungkinan akan ada lebih dari satu jawaban yang benar.

Metode klose dalam pembelajaran bahasa digunakan sebagai latihan untuk membantu siswa dalam mempelajari bahasa. Terutama dalam diskusi akan ada jawaban yang tepat untuk mengisi kekosongan.

Berdasarkan uraian-uraian di atas, dapat disimpulkan bahwa metode klose adalah suatu teknik pengajaran membaca pemahaman dengan cara menghapus kata dalam wacana, dengan cara-cara tertentu. Penghapusan kata tidak bermaksud merusak makna wacana akan tetapi makna wacana tetap seperti semula dan pembaca mengisi kata yang dikosongkan dengan memilih kata yang tepat boleh sinonimnya sehingga pembaca dapat menerka arti kalimat dari kata-kata sebelum dan sesudah kata yang dihilangkan.

\section{METODE PENELITIAN}

\section{Metode Intervensi Tindakan}

Penelitian ini menggunakan metode penelitian tindakan kelas (PTK) merupakan penelitian tindakan mengenai kelas artinya penelitian yang dilakukan di seputar kelas. Penelitian tindakan kelas ini terdiri dari empat tahapan: (1) perencanaan, (2) tindakan, (3) pengamatan, dan (4) refleksi. Keempat tahapan tersebut terjalin dalam satu siklus. Penelitian ini direncanakan ada dua siklus, adapun tujuannya adalah untuk memperbaiki efektivitas dan efisiensi praktik pendidikan.

\section{Desain Intervensi Tindakan}

Desain penelitian ini menggunakan model Spiral. Penelitian tindakan kelas menurut Kemmis dan Mc Taggart yang terdiri dari empat komponen, yaitu (a) perencanaan, (b) tindakan, (c) pengamatan, dan (d) refleksi. Hubungan keempat komponen tersebut dipandang sebagai satu siklus.

\section{Subjek dan Partisipan dalam Penelitian}

Subjek dalam penelitian ini adalah siswa kelas V siswa gangguan intelektual ringan di SDLB C Dian Kahuripan berjumlah empat siswa yang belum mempunyai kemampuan dalam membaca pemahaman berdasarkan pretest yang dilakukan oleh peneliti. Adapun partisipan dalam penelitian ini adalah guru kelas $\mathrm{V}$, 
peneliti dan teman sejawat sebagai kolaborator yaitu guru yang dinilai memahami tentang pembelajaran membaca pemahaman.

\section{Instrumen Pengumpulan Data}

Dalam penelitian ini untuk mendapatkan data hasil membaca pemahaman, instrumen yang dikembangkan berbentuk tes membaca pemahaman pilihan ganda. Pemberian skor dengan menggunakan skala dikotomi yaitu jawaban benar nilai 1 dan jawaban salah nilai 0 .

Proses penyusunan instrumen diawali dengan penyusunan kisi-kisi berdasarkan Kurikulum Tingkat Satuan Pendidikan 2006 dengan materi membaca pemahaman teks bacaan sastra dan nonsastra. Di samping itu, penyusunan instrumen dengan pertimbangan dan masukan pembimbing.

\section{Teknik Pengumpulan Data dan Instrumen}

\section{Data Pemantau Tindakan}

Teknik nontes, yaitu dengan menggunakan observasi teman sejawat (kolaborator). Pengamatan dilakukan secara langsung dengan dibantu kamera.

2. Data Penelitian

Teknik tes, berupa data hasil tes awal sebelum diberikan tindakan dan tes setelah diberikan tindakan.

\section{Teknik Analisa Data dan Interpretasi}

1. Analisis data kuantitatif dalam penelitian ini yaitu tindakan dinyatakan berhasil bila telah mencapai ketuntasan belajar sesuai dengan kriteria ketuntasan minimal yang telah direncanakan sebesar $60 \%$. Analisis data yang dilakukan berupa hasil tes kemampuan membaca pemahaman. Untuk menghitung persentase hasil belajar siswa, peneliti menggunakan rumus jumlah skor pencapaian dibagi skor maksimum kali seratus.

2. Analisis data kualitatif bertujuan untuk melihat semua proses selama berlangsungnya penelitian tindakan yang meliputi partisipasi dan keterlibatan siswa, kolaborator, kekuatan, dan kelemahan yang terjadi selama tindakan. Hasil analisis data berupa diskripsi hasil pengamatan dari semua proses pembelajaran kemampuan siswa gangguan intelektual ringan kelas $\mathrm{V}$ dalam membaca pemahaman melalui metode klose.

\section{HASIL DAN PEMBAHASAN}

\section{Siklus I}

\section{Perencanaan}

Siklus I direncanakan terdiri dari empat kali pertemuan. Pertemuan pertama menyajikan materi bacaan berjudul Baru Kelinting. Pertemuan kedua menyimpulkan isi bacaan dan menjelaskan kembali isi bacaan. Pertemuam ketiga menyajikan materi bacaan berjudul Memberantas Hama dan pertemuan keempat menyimpulkan isi teks bacaan.

2. Tindakan

Pertemuan pertama, guru melakukan apersepsi. Pada kegiatan inti guru membagikan lembar teks bacaan yang berjudul Baru Kelinting yang telah berbentuk klose kepada setiap siswa. Setelah membaca siswa diberi penjelasan cara mengisi delisi pada teks di kertas manila yang terdapat di papan tulis dan siswa boleh berdiskusi tetapi tidak menyontek. Guru bersama siswa berdiskusi mengenai jawaban siswa serta memperlihatkan teks asli kepada siswa. Guru mengakhiri pelajaran dengan memberikan tugas rumah.

Pertemuan kedua, guru membahas dan menilai tugas rumah siswa. Guru membagikan dan menilai lembar evaluasi teks bacaan klose.

Pertemuan ketiga, guru melakukan apersepsi. Pada kegiatan inti, guru membagikan lembar teks bacaan yang berjudul "Memberantas Hama" yang telah berbentuk klose kepada setiap siswa. Setelah membaca, siswa diberi penjelasan cara mengisi delisi pada teks di kertas manila di papan tulis dan siswa boleh berdiskusi tapi tidak menyontek. Guru bersama siswa berdiskusi pada jawaban siswa serta memperlihatkan teks asli kepada siswa. Guru mengakhiri pelajaran dengan memberikan tugas rumah.

Pertemuan keempat, guru membahas dan menilai tugas rumah siswa. Guru membagikan dan menilai lembar evaluasi teks bacaan klose.

Sebelum melaksanakan siklus I, peneliti melakukan tes awal. Hasil tes kemampuuan awal siswa membaca pemahaman dapat dilihat pada tabel 1. Sedangkan Hasil Tes Siklus I tertera pada tabel 2.

Tabel 1. Hasil Tes Kemampuan prasiklus Membaca Pemahaman

\begin{tabular}{|c|c|c|}
\hline No & Nama Siswa & Kemampuan Prasiklus \\
\hline 1 & HT & $28 \%$ \\
\hline 2 & BF & $23 \%$ \\
\hline 3 & RP & $15 \%$ \\
\hline 4 & KS & $25 \%$ \\
\hline \multicolumn{2}{|c|}{ Rerata } & $22,75 \%$ \\
\hline
\end{tabular}

Skor Maksimum 30

Tabel 2. Hasil Tes Kemampuan siklus I Membaca Pemahaman

\begin{tabular}{|c|c|c|}
\hline No & Nama Siswa & Kemampuan Prasiklus \\
\hline 1 & HT & $56,8 \%$ \\
\hline 2 & BF & $55,7 \%$ \\
\hline 3 & RP & $49,6 \%$ \\
\hline
\end{tabular}




\begin{tabular}{|c|c|c|}
\hline No & Nama Siswa & Kemampuan Prasiklus \\
\hline 4 & KS & $50,0 \%$ \\
\hline \multicolumn{3}{|c|}{ Rerata } \\
\hline
\end{tabular}

Skor Maksimum 30

Berdasarkan kemampuan di atas, belum mencapai kriteria ketuntasan minimal yang diharapkan sebesar $60 \%$, maka peneliti melanjutkan ke siklus II.

\section{Pengamatan}

Dilakukan oleh peneliti dengan observer, yaitu Suryantinah terhadap pelaksanaan tindakan pembelajaran membaca pemahaman dengan metode klose dan kekurangan-kekurangan rencana yang perlu perbaikan.

\section{Refleksi}

Adapun temuan-temuan yang perlu diperbaiki, yaitu diantaranya siswa belum semua mengisi sendiri delisi teks bacaan, belum aktif mengajukan pilihan jawaban, belum berani melukiskan jawaban di depan kelas, belum semua pertanyaan guru terjawab, dan siswa kurang percaya diri dalam mengerjakan evaluasi. Kesimpulan peneliti melakukan refleksi berupa peningkatan kemampuan belajar siswa dan membuat perencanaan perbaikan untuk pelaksanaan siklus II.

\section{Siklus II}

\section{Perencanaan}

Siklus II direncanakan terdiri dari empat pertemuan. Peneliti mempersiapkan materi pembelajaran yang disusun sesuai dengan rencana pembelajaran serta mempersiapkan media yang digunakan yang hampir sama dengan siklus I, tetapi diberikan diberikan perbaikan-perbaikan berdasarkan hasil refleksi siklus I. Teks bacaan pada siklus II berbeda dengan siklus I, tetapi masih dalam materi pokok yang sama yaiti bacaan fiksi dan nonfiksi. Hal ini dimaksudkan agar siswa tidak jenuh belajar dan terus termotivasi dengan cerita baru maupun bacaan baru, sehingga sekaligus akan menambah ilmu dan wawasan mereka.

Adapun tes yang digunakan tetap disesuaikan dengan kisi-kisi evaluasi yang ada, sehingga tidak mengurangi bobot soal walaupun teks bacaan berbeda. Teks bacaan pada siklus ini berjudul “Timun Emas dan Kesenian Wayang Golek".

2. Tindakan

Pertemuan pertama, guru melakukan apersepsi. Pada kegiatan inti, guru membagikan lembar teks bacaan yang berjudul "Timun Emas" yang telah berbentuk klose kepada setiap siswa. Setelah membaca siswa diberi penjelasan cara mengisi delisi pada teks di kertas manila yang terdapat di papan tulis dan siswa boleh berdiskusi tapi tidak menyontek. Guru bersama siswa berdiskusi pada jawaban siswa serta memperlihatkan teks asli kepada siswa. Guru mengakhiri pelajaran dengan memberikan tugas rumah.

Pertemuan kedua, guru membahas dan menilai tugas rumah siswa. Guru membagikan dan menilai lembar evaluasi teks bacaan klose.

Pertemuan ketiga, guru melakukan apersepsi. Pada kegiatan inti, guru membagikan lembar teks bacaan yang berjudul "Kesenian Wayang Golek" yang telah berbentuk klose kepada setiap siswa. Setelah membaca, siswa diberi penjelasan cara mengisi delisi pada teks di kertas manila di papan tulis dan siswa boleh berdiskusi tetapi tidak menyontek. Guru bersama siswa berdiskusi pada jawaban siswa serta memperlihatkan teks asli kepada siswa. Guru mengakhiri pelajaran dengan memberikan tugas rumah.

Pertemuan keempat, guru membahas dan menilai tugas rumah siswa. Guru membagikan dan menilai lembar evaluasi teks bacaan klose. Hasil Tes Siklus II tertera pada tabel 3.

Tabel 3. Hasil Tes Kemampuan siklus II Membaca Pemahaman

\begin{tabular}{|c|c|c|}
\hline No & Nama Siswa & Kemampuan Prasiklus \\
\hline 1 & HT & $76,6 \%$ \\
\hline 2 & BF & $75,4 \%$ \\
\hline 3 & RP & $69,6 \%$ \\
\hline 4 & KS & $70,7 \%$ \\
\hline \multicolumn{2}{|c|}{ Rerata } & $73,07 \%$ \\
\hline
\end{tabular}

\section{Skor Maksimum 30}

\section{Pengamatan}

Pada siklus II diperoleh hasil yang memuaskan karena telah dilakukan perbaikan kekurangankekurangan pada siklus I serta antusias siswa yang tinggi terhadap pembelajaran ini.

\section{Refleksi}

Berdasarkan hasil pengamatan yang dilakukan, refleksi siklus I sudah dilaksanakan pada siklus II dengan hasil yang memuaskan. Hal ini terbukti antara lain: (1) semua siswa lancer dalam mengisi delisi; (2) semua siswa aktif dan percaya diri dalam prosess pembelajaran ditandai dengan siswa berani mengungkapkan pendapatnya; (3) terjadinya komunikasi multi arah, yaitu antara guru dan siswa dan antara siswa dengan siswa yang terjadi ketika berdiskusi; (4) siswa mampu memahami langkah-langkah metode klose dengan dengan baik; dan (5) siswa lebih berkonsentrasi dan tenang dalam mengerjakan evaluasi, sehingga hasil penguasaan siswa terhadap materi pelajaran memuaskan, yaitu sebesar 73,07 \%. Dengan demikian, hasil sudah melebihi kriteria ketuntasan minimal yang

Perspektif Ilmu Pendidikan - Vol. 25 Th. XVI April 2012 
ditargetkan maka peneliti dan observer memutuskan untuk mengakhiri tindakan pada siklus II ini.

\section{Analisis Data}

Di bawah ini disajikan tabel 4, yang berisi hasil penguasaan materi membaca pemahaman dari sebelum tindakan hingga setelah tindakan serta pencapaian ketuntasan siswa sebagai berikut.

Tabel 4. Hasil Penguasaan Membaca Pemahaman

\begin{tabular}{|c|c|c|c|c|c|c|}
\hline \multirow[b]{2}{*}{ No } & \multirow[b]{2}{*}{$\begin{array}{l}\text { Nama } \\
\text { Siswa }\end{array}$} & \multicolumn{3}{|c|}{ Persentasi Penguasaan } & \multirow{2}{*}{$\begin{array}{l}\text { Kriteria } \\
\text { Ketun- } \\
\text { tasan } \\
\text { Minimal }\end{array}$} & \multirow[b]{2}{*}{ Ket } \\
\hline & & $\begin{array}{l}\text { Pra- } \\
\text { siklus }\end{array}$ & $\begin{array}{l}\text { Sik- } \\
\text { lus I }\end{array}$ & $\begin{array}{c}\text { Siklus } \\
\text { II }\end{array}$ & & \\
\hline 1 & $\mathrm{HT}$ & $28 \%$ & $56,8 \%$ & $76,6 \%$ & $60 \%$ & Tuntas \\
\hline 2 & $\mathrm{BF}$ & $23 \%$ & $55,7 \%$ & $75,4 \%$ & $60 \%$ & Tuntas \\
\hline 3 & $\mathrm{RP}$ & $15 \%$ & $49,6 \%$ & $69,6 \%$ & $60 \%$ & Tuntas \\
\hline 4 & KS & $25 \%$ & $50,0 \%$ & $70,7 \%$ & $60 \%$ & Tuntas \\
\hline \multicolumn{2}{|c|}{ Rerata } & $22,75 \%$ & $53,3 \%$ & $73,07 \%$ & $60 \%$ & Tuntas \\
\hline
\end{tabular}

Berdasarkan analisis data dari masing-masing siklus, pada tabel dapat dilihat tingkat penguasaan siswa terhadap pembelajaran pada penelitian tindakan di setiap siklusnya, serta ketuntasan masing-masing siswa. Oleh sebab itu, peneliti menghentikan tindakan sampai pada siklus II karena pada siklus yang terakhir ini sudah menunjukkan pencapaian ketuntasan belajar siswa.

\section{Implikasi}

Metode klose dapat memberikan dapat diterapkan pada pembelajaran membaca pemahaman bagi siswa dengan gangguan intelektual ringan melalui serangkaian kegiatan di antaranya mengisi delisi, melukiskan jawabannya di papan tulis kemudian mendiskusikannya sehingga siswa merasa lebih mudah memahami isi bacaan dan dapat menyelesaikan soal-soal yang berkaitan dengan bacaan.

\section{PENUTUP}

\section{Kesimpulan}

Berdasarkan hasil yang diperoleh pada siklus I sebesar 53,3\% dan pada siklus II sebesar 73,07\%, maka dapat disimpulkan bahwa metode klose dapat meningkatkan kemampuan membaca pemahaman.

\section{Saran}

Bagi guru, dapat menggunakan metode klose dalam pembelajaran membaca untuk siswa yang sudah lancar membaca.

Bagi sekolah, melalui penerapan metode klose dalam pembelajaran membaca pemahaman dapat meningkatkan mutu pembelajaran bahasa Indonesia bagi siswa dengan gangguan intelektual ringan.

\section{DAFTAR PUSTAKA}

Abdurrachman, M. \& Sudjadi. (1994). Pendidikan luar biasa umum. Jakarta: Direktorat Jenderal Pendidikan Tinggi Depdikbud.

Alimin, Z. (2007). Model pembelajaran anak. Diakses tanggal 29 Desember 2011 dari situs http:/ / zalimin.blogspot.com/2007/07/model-pembelajaran-anak.html

Amin, M. (1995). Ortopedagogik anak tunagrahita. Jakarta: Direktorat Jenderal Pendidikan Tinggi Depdikbud.

Arikunto, S. (2006). Penelitian tindakan kelas. Jakarta: Bumi Aksara.

Broto, A.S. (1990). Pengajaran bahasa Indonesia sebagai bahasa kedua di sekolah dasar berdasarkan pendekatan linguistik konstruktif. Jakarta: Bulan Bintang.

Efendi, M. (2006). Pengantar psikopedagogik anak berkelainan. Jakarta: Bumi Aksara.

Hayon, J. (2003). Membaca dan menulis wacana. Jakarta: Storia Grafika.

Karlin, R. (1984). Teaching reading in high school. New York: Happer and Row Publisher. Inc.

Kosadi, H, dkk. (1990). Strategi belajar mengajar bahasa Indonesia. Jakarta: Binacipta.

Lumbantobing, S.M. (2001). Anak dengan terbelakang mental. Jakarta: Fakultas Kedokteran Universitas Indonesia.

Rahim, F. (2007). Pegajaran membaca di sekolah dasar. Jakarta: Bumi Aksara.

Rahman, M.A. (2003). Pendidikan bagi anak kesulitan belajar. Jakarta: Rineka Cipta.

Riadi, S., dkk. (1984). Identifikasi dan evaluasi anak luar biasa. Jakarta: Direktorat Jenderal Pendidikan Dasar dan Menengah.

Rochyadi, E. \& Alimin, Z. (2005). Pengembangan program pembelajaran individual bagi anak tunagrahita. Jakarta: Depdiknas Dirjen Dikti.

Subyantoro \& Pratiwi, Y. (2000). Membaca II. Jakarta: Universitas Terbuka.

Sugono, D. (2003). Buku praktis bahasa Indonesia. Jakarta: Bulan Bintang.

Sunardi. (1997). Menangani kesulitan belajar membaca. Jakarta: Badan Penelitian dan Pengembangan Depdikbud.

Tim Penulis Bahasa Indonesia UT- ASMI. (2002). Buku materi pokok bahasa Indonesia. Jakarta: Universitas Terbuka. 